\title{
First records of melanistic Euglossa (Hymenoptera: Apidae): evolutionary implications
}

\author{
Nemésio, $A{ }^{a}{ }^{*}$ and Martins, $C F .^{b}$ \\ ${ }^{a}$ Instituto de Biologia, Universidade Federal de Uberlândia. Rua Ceará, S/N, Campus Umuarama, \\ CEP 38400-902, Uberlândia, MG, Brazil \\ ${ }^{b}$ Departamento de Sistemática e Ecologia, Centro de Ciências Exatas e da Natureza, Universidade Federal da Paraíba, \\ CEP 58059-900 João Pessoa, PB, Brazil \\ *e-mail: andre.nemesio@gmail.com
}

Received June 23, 2012 - Accepted September 17, 2012 - Distributed August 31, 2013

Neotropical orchid bees (Hymenoptera: Apidae: Euglossina) are conspicuous due to their vivid and metallic colors. Nevertheless, except for a few comments, usually concerning the appropriateness of using coloration as a taxonomic character (e.g. Rebêlo and Moure, 1996; Nemésio, 2005, 2009; Bembé, 2007), virtually nothing is known about color production and evolution in orchid bees. Based on studies on other organisms, it is hypothesized that orchid-bee setae are primarily pigmentcolored, whereas integument due its color to chemical (pigments) and physical (light refraction or reflection) factors (Nemésio, 2009). Very few color aberrations have been noticed among orchid bees, most of them concerning color alteration of setae, especially in Eulaema (e.g. Nemésio, 2002). No integumental color alteration has been reported in orchid bees to date.

During surveys of orchid bees in northeastern Brazil (states of Paraíba and Pernambuco), two aberrant specimens of Euglossa carolina Nemésio, 2009 were collected. All characters (overall size, shape of metatiba, shape of mesotibial tufts, length of paraocular ivory markings and ivory markings on the scapes, punctation - see Figures 1 and 2) clearly correspond to those of ordinary E. carolina specimens, except integument coloration. The specimen from Pernambuco (Figure 1) is entirely blackish, whereas the specimen from Paraíba (Figure 2), presents blackish coloration especially on frons, mesosoma and metasoma (Figure 2A-C). On each tergum, only a tiny distal stripe of green coloration remains (Figure 2A-B).

Among Apini, vivid metallic colors are usually considered an apomorphy of Euglossina (Oliveira, 2006). Nevertheless, members of Eulaema usually lack metallic colors and present black integument, except for some metallic hues on terga of members of the subgenus Eulaema and on the distal three terga of Eulaema (Apeulaema) nigrita Lepeletier, 1841. It is noticeable, however, that Eulaema has never been considered a basal clade within Euglossina (see Kimsey, 1982, 1987; Michener, 1990; Engel, 1999; Oliveira, 2006; Ramírez et

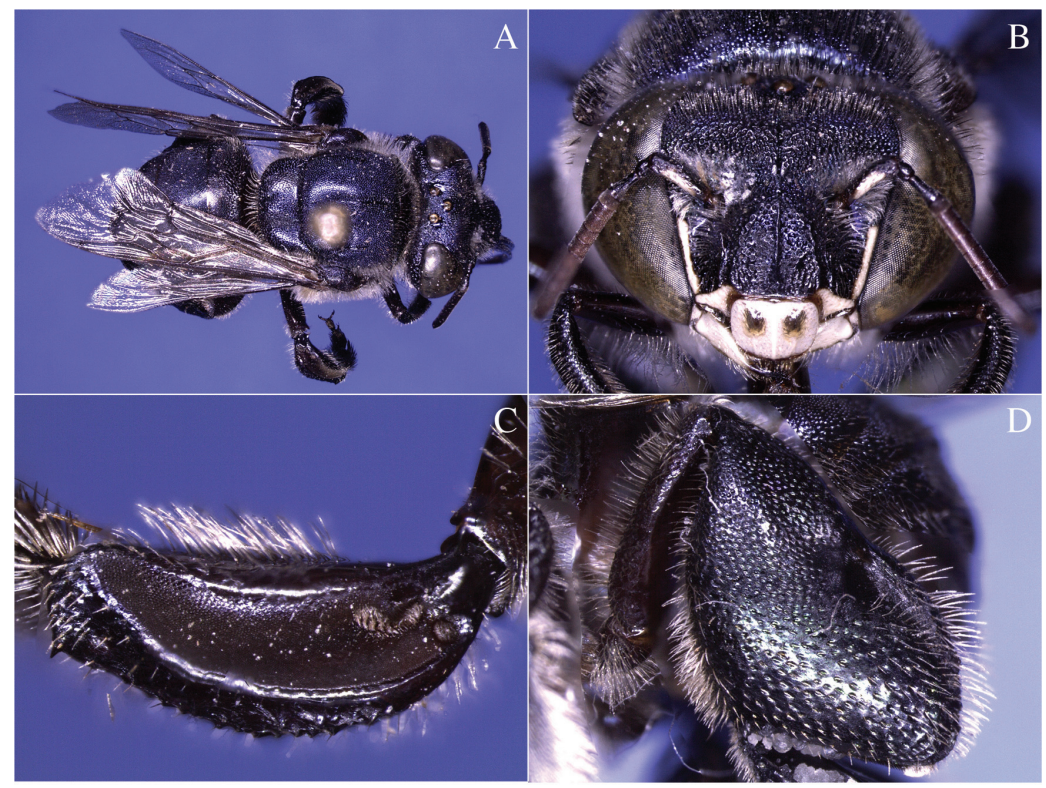

Figure 1 - Melanistic Euglossa carolina Nemésio, 2009 from Pernambuco, showing overall blackish integument. A: dorsal view; $B$ : frontal view of face; $C$ : ventral side of mesotibia; $D$ : metatibia. 


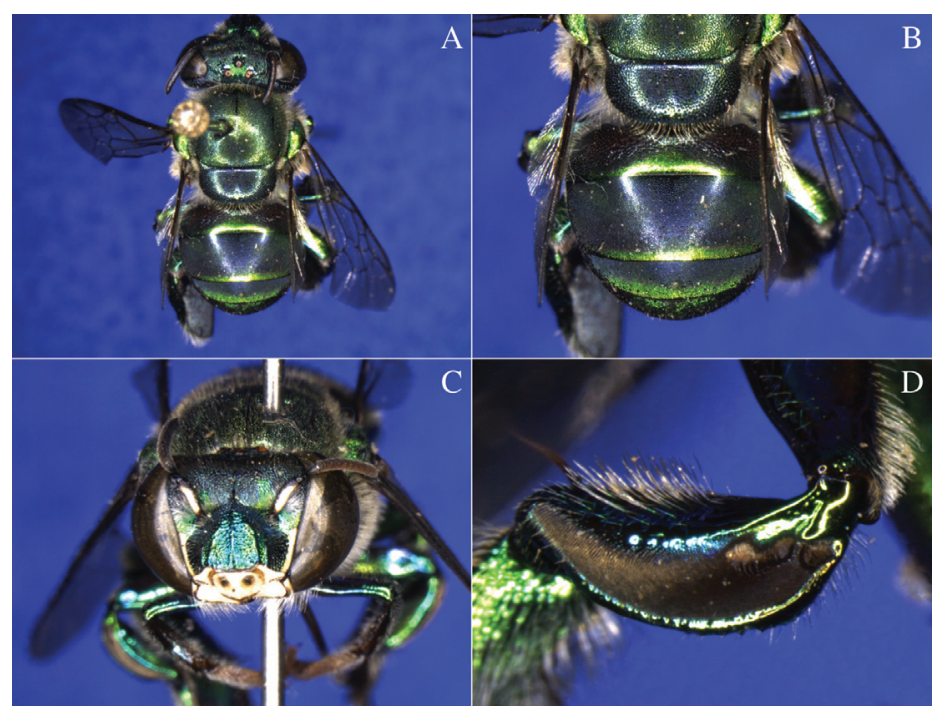

Figure 2 - Partial melanistic Euglossa carolina Nemésio, 2009 from Paraíba, showing blackish integument on frons, mesosoma and metasoma. A: dorsal view; B: scutellum and metasoma; C: frontal view of face; D: ventral side of mesotibia.

al., 2010). On the contrary, genera comprising only species with metallic colors have usually been presented as potential basal clades, as Aglae (see Kimsey, 1982; Oliveira, 2006) and Exaerete (see Ramírez et al., 2010). If our current knowledge is correct, it is highly possible that the common ancestor of all orchid bees presented metallic coloration, and the blackish integument of Eulaema, some Eufriesea and even some Euglossa belonging to the E. decorata Smith, 1874 reveals the loss of this character in most (Eulaema) or in some parts (Eufriesea and E. decorata and allies) of their integuments.

The record of these mutant blackish E. carolina is the first evidence that reversion of metallic green to blackish integument is possible and occurs naturally, supporting the current view tha Eulaema is possibly a derived clade within Euglossina. Hopefully, this finding can call attention to this mostly unexplored and outstanding feature of orchid bees: production and evolution of colors.

The specimens here reported are currently deposited at the Entomological Collection of the 'Universidade Federal de Minas Gerais', with the following label data: (i) "Igarassu, PE, Ref. Charles Darwin, Brasil, 02.02.2000, C. Schlindwein leg." and "Euglossa (Euglossa) sp. n. 2, Moure det. 2000"; (ii) "UFPB Campus I 14431-42596" and "João Pessoa, PB, Brasil, 17/01/2004, D.M. e Silva" and "Euglossa (Euglossa) carolina, Nemésio, 2009, A. Nemésio det. 2009”.

Acknowledgments - We are grateful to Dr. Clemens P. Schlindwein for making the specimen illustrated in Figure 1 available to us.

\section{References}

BEMBÉ, B., 2007. Revision der Euglossa cordata-Gruppe und Untersuchungen zur Funktionsmorphologie und Faunistik der Euglossini (Hymenoptera, Apidae). Entomofauna, Supplement, vol. 14, p. 1-146.
ENGEL, MS. 1999. The first fossil Euglossa and phylogeny of the orchid bees (Hymenoptera: Apidae; Euglossini). American Museum Novitates, vol. 3272, p. 1-14.

KIMSEY, LS., 1982. Systematics of bees of the genus Eufriesea. University of California Publications in Entomology, vol. 95, p. 1-125.

-, 1987. Generic relationships within the Euglossini (Hymenoptera, Apidae). Systematic Entomology, vol. 12, p. 63-72.

LEPELETIER DE SAINT FARGEAU, ALM., 1841. Histoire Naturelle des Insectes, Hyménoptères. Paris: Librairie Encyclopédique de Roret. 680 p. vol. 2.

MICHENER, CD., 1990. Classification of the Apidae (Hymenoptera). University of Kansas Science Bulletin, vol. 54, p. 75-164.

NEMÉSIO, A., 2002. Notes on the occurrence of an aberrant coloration in Eulaema nigrita (Hymenoptera: Apidae: Euglossina) in forest fragments in Southeastern Brazil. Lundiana, vol. 3, p. 75-77.

-, 2005. Fluorescent colors in orchid bees (Hymenoptera: Apidae). Neotropical Entomology, vol. 34, p. 933-936.

-, 2009. Orchid bees (Hymenoptera: Apidae) of the Brazilian Atlantic Forest. Zootaxa, vol. 2041, p. 1-242.

OLIVEIRA, ML., 2006. Nova hipótese de relacionamento filogenético entre os gêneros de Euglossini e entre as espécies de Eulaema Lepeletier, 1841 (Hymenoptera: Apidae: Euglossini). Acta Amazonica, vol. 36, p. 273-286.

RAMÍREZ, SR., ROUBIK, DW., SKOV, C. and PIERCE, NE. 2010. Phylogeny, diversification patterns and historical biogeography of euglossine orchid bees (Hymenoptera: Apidae). Biological Journal of the Linnean Society, vol. 100 , p. 552-572.

REBÊLO, JMM. and MOURE, JS. 1996. [1995] As espécies de Euglossa Latreille do nordeste de São Paulo (Apidae, Euglossinae). Revista Brasileira de Zoologia, vol. 12, p. 445-466.

SMITH, F., 1874. A revision of the genera Epicharis, Centris, Eulema and Euglossa, belonging to the family Apidae, section Scopulipedes. Annual Magazine of Natural History, vol. 4, p. 440-446. 